\title{
2,3-cis-2R,3R-(-)-epiafzelechin-3-O-p-coumarate, a novel flavan-3-ol isolated from Fallopia convolvulus seed, is an estrogen receptor agonist in human cell lines
}

Jennifer C Brennan ${ }^{1 *}$, Michael S Denison', Dirk M Holstege², Prokopios Magiatis ${ }^{3}$, Jerry L Dallas ${ }^{4}$, Elisa G Gutierrez ${ }^{5}$, Anatoly A Soshilov ${ }^{1}$ and James R Millam ${ }^{6}$

\begin{abstract}
Background: The plant genus Fallopia is well-known in Chinese traditional medicine and includes many species that contain bioactive compounds, namely phytoestrogens. Consumption of phytoestrogens may be linked to decreased incidence of breast and prostate cancers therefore discovery of novel phytoestrogens and novel sources of phytoestrogens is of interest. Although phytoestrogen content has been analyzed in the rhizomes of various Fallopia sp., seeds of a Fallopia sp. have never been examined for phytoestrogen presence.

Methods: Analytical chemistry techniques were used with guidance from an in vitro estrogen receptor bioassay (a stably transfected human ovarian carcinoma cell line) to isolate and identify estrogenic components from seeds of Fallopia convolvulus. A transiently transfected human breast carcinoma cell line was used to characterize the biological activity of the isolated compounds on estrogen receptors (ER) a and $\beta$.

Results: Two compounds, emodin and the novel flavan-3-ol, (-)-epiafzelechin-3-O-p-coumarate (rhodoeosein), were identified to be responsible for estrogenic activity of $F$. convolvulus seed extract. Absolute stereochemistry of rhodoeosein was determined by 1 and 2D NMR, optical rotation and circular dichroism. Emodin was identified by HPLC/DAD, LC/MS/MS, and FT/ICR-MS. When characterizing the ER specificity in biological activity of rhodoeosein and emodin, rhodoeosein was able to exhibit a four-fold greater relative estrogenic potency (REP) in breast cells transiently-transfected with ERß as compared to those transfected with ERa, and emodin exhibited a six-fold greater REP in ERß-transfected breast cells. Cell type-specific differences were observed with rhodoeosein but not emodin; rhodoeosein produced superinduction of reporter gene activity in the human ovarian cell line (> 400\% of maximum estradiol [E2] induction) but not in the breast cell line.

Conclusion: This study is the first to characterize the novel flavan-3-ol compound, rhodoeosein, and its ability to induce estrogenic activity in human cell lines. Rhodoeosein and emodin may have potential therapeutic applications as natural products activating ER $\beta$, and further characterization of rhodoeosein is necessary to evaluate its selectivity as a cell type-specific ER agonist.
\end{abstract}

Keyword: Fallopia convolvulus, Phytoestrogens, Bioassay-directed fractionation, HPLC/MS/NMR, (-)-epiafzelechin-3O-p-coumarate (rhodoeosein), Emodin, Transfection, Estrogen receptor, Relative estrogenic potency

\footnotetext{
* Correspondence: jcbrennan@ucdavis.edu

'Department of Environmental Toxicology, University of California, One

Shields Avenue, Davis, CA 95616, USA

Full list of author information is available at the end of the article
} 


\section{Background}

The plant genus Fallopia (Polygonacae) is well known in traditional medicines, and extracts have been used to treat hepatitis, liver damage, inflammation, and postmenopausal diseases [1-4]. Compounds isolated from rhizomes of Fallopia sp. have demonstrated vasorelaxant, anti-oxidant, anti-bacterial, anti-inflammatory, and antitumor properties [4-7], which have likely led to the Fallopia genus being widely used in traditional Chinese medicines. Several polyphenolic compounds exhibiting estrogenic activity (phytoestrogens) have also been isolated from the roots and rhizomes of numerous Fallopia (recently Polygonum) species such as F. multiflorum, F. cuspidatum, and F. japonica [8-12]. Many phytoestrogens exhibit preferential activation of estrogen receptor beta $(E R \beta)$ over estrogen receptor alpha $(E R \alpha)$ [13], and diets high in phytoestrogen content have been correlated with lower incidence of hormone-related cancers, namely breast and prostate [14]. ER $\beta$ activation has an antiproliferative effect in breast cells and is viewed as a protective balance against ER $\alpha$ activation (associated with proliferation) [15-17]. As such, there is interest in identifying plant sources rich in phytoestrogen content as well as discovering novel ER $\beta$-selective phytoestrogens.

Recently, the rhizomes of Fallopia convolvulus (L.) Á. Löve (black bindweed, Polygonum convolvulus L. [18]) were examined for their inhibitory effects on nitric oxide production in lipopolysaccaharide-activated macrophages. Seventeen known and three novel phenolic compounds were identified in the active extract [19]. However, extracts of $F$. convolvulus have not been examined for estrogenic activity nor has the polyphenolic content of its seeds been studied. Additionally, despite the wealth of information on the polyphenolic content and/or bioactive properties in the genus Fallopia, no attention has been paid to the content of the seeds. F. convolvulus is a widely distributed species, native throughout Asia, Europe, and northern Africa and invasive in the Americas and Australia [20]. Study of ancient herb consumption in northern Europe indicates that the seeds of $F$. convolvulus were consumed by humans in early preRoman Iron Age and the Roman Iron Age (500 BC-400 AD) $[21,22]$.

Several major classes of phytoestrogens exist including isoflavones, lignans, stilbenes such as resveratrol, and anthraquinones such as emodin and emodin-glycoside. Flavanols, a class rich in biologically active compounds, may undergo metabolism into ligands with estrogenic activity [23]. For identifying phytoestrogens in the Fallopia genus, mass spectrometry (MS), rather than diode array detection (DAD) or ultra-violet (UV) absorption, has become the method of choice due to its high specificity and ability to characterize unknowns through fragmentation, with electrospray ionization (ESI) being the predominant ionization source. The bulk of estrogenic compounds in Fallopia identified by MS are anthraquinones, stilbenes, and phenylpropanoids [6,9,10,24]. Fourier-transform ion cyclotron resonance (FTICR) MS has been used to determine accurate mass (and elemental composition), of estrogenic compounds [25]. ${ }^{1} \mathrm{H}-\mathrm{NMR}$ and ${ }^{13} \mathrm{C}$ - NMR, have been used to elucidate the structure of many polyphenolic components from the genus Fallopia [19,26,27]. However, if the polyphenols contain chiral centers, NMR analysis will only yield the relative stereochemistry of the compound, and it is then necessary to use either X-ray crystallography or optical rotation combined with circular dichroism to determine the absolute stereochemistry [28]. To identify compounds with certain biologic activity in a complex matrix, toxicant identification evaluation (TIE) combines chromatography separation and bioassay analysis to achieve rapid screening, isolation, and identification of compounds of interest. TIE studies have been applied successfully to the genus Fallopia to isolate and identify compounds with estrogenic, antibacterial, anti-HIV, or anti-inflammatory properties ([10,29-31]). Use of the estrogen-sensitive carcinoma cell line MCF-7 guided separation of the phytoestrogens emodin and emodin 8-O- $\beta$-D-glucopyranoside from a methanolic root extract of F. cuspidatum [8]. These two compounds in addition to citreorosein were isolated from F. cuspidatum using a recombinant yeast screening assay (YES) [29]. Our objective was to determine whether the seeds of $F$. convolvulus contain compounds which display estrogenic activity (phytoestrogens), and, if so, the identity of the responsible compounds and whether they displayed ER $\beta$-selectivity. In this study the estrogenic activity of F. convolvulus seed extract was evaluated using the stably transfected recombinant human ovarian carcinoma BG1Luc4E2 cell line which contains an estrogenresponsive reporter gene [32]. Through TIE, active (estrogenic) components were isolated from $F$. convolvulus seed and identified by instrumental analyses, and the transiently-transfected human breast carcinoma SKBR3 cell line was used to assess ER subtype-selectivity of the isolated estrogenic components.

\section{Methods}

\section{Chemicals and standards}

Restriction enzymes were purchased from New England Biolabs (Ipswich, MA), and antibodies were from Santa Cruz Biotechnology, Inc (Santa Cruz, CA). Translation grade L-[35S]-methionine $(>400 \mathrm{Ci} / \mathrm{mmol})$ was purchased from MP Biomedical (Solon, $\mathrm{OH}$ ). Standards 17$\beta$-estradiol (E2), emodin, and genistein were obtained from Sigma Aldrich Chemical Company (St. Louis, MO). Molecular grade dimethyl sulfoxide (DMSO) was obtained from OmniPur. Molecular grade ethanol $(\mathrm{EtOH})$ and HPLC-grade solvents ethyl acetate (EtOAc) 
and $n$-hexane (n-hex) were obtained from Sigma (St. Louis, MO); HPLC-grade solvents acetonitrile (ACN), water, glacial acetic acid (HOAc), and methanol $(\mathrm{MeOH})$ were obtained from Fisher Scientific (Waltham, MA). Deuterated dimethyl sulfoxide (DMSO, 99.9\%) was obtained from Cambridge Isotope Laboratories (Andover, MA), and silica gel (170-400 mesh) was obtained from Fisher Scientific. Premium and charcoal-stripped fetal bovine serum (FBS) were obtained from Atlanta Biologicals (Lawrenceville, GA), Alpha Minimal Essential Medium $(\alpha-M E M)$ was obtained Invitrogen (San Diego, CA), Dulbecco's Modified Eagle's Medium (DMEM) was obtained from Sigma (St. Louis, MO), Lipofectamine 2000 transfection reagent was from Invitrogen (San Diego, CA), and Cell Culture Lysis Buffer and Passive Lysis Buffer were from Promega (Madison, WI). Protein Assay Dye Reagent Concentrate was from Bio-Rad (Hercules, CA). Seeds (catalogue numbers 11716 and 11717 for F. convolvulus and $F$. dumetorum, respectively) were purchased from Herbiseed Company (Twyford, United Kingdom), and species authenticity was verified by Dr. Martin Parham (Herbiseed). SKBR3 cells were purchased from ATCC (Manassas, VA). All standards were stored at $4^{\circ} \mathrm{C}$ +in borosilicate amber vials (Fisher Scientific) with PTFElined caps.

\section{General experimental procedures}

HPLC for DAD and purification was performed using an Agilent series 1100 HPLC instrument equipped with a quaternary pump, autosampler, degasser, and Agilent Chemstation software for LC 3D systems. A Phenomenex Luna $\mathrm{C}_{18}$ column $(150 \mathrm{~mm} \times 4.6 \mathrm{~mm}$ I.D., $5 \mu \mathrm{m})$ with an Alltech guard column (Econosphere $\mathrm{C}_{18}, 5 \mu \mathrm{m}$ ) was used at $23^{\circ} \mathrm{C}$. LC/MS/MS analysis was performed using a triple quadrupole mass spectrometer API 2000 (PE Sciex, Concord, Ontario, Canada) operated in negative mode electrospray ionization (ESI) and a Perkin-Elmer (PE) series 200 equipped with a series 200 pump (PE), series 200 autosampler (PE), a CT0-10A column oven (Shimadzu), and DGU-14A degasser (Shimadzu) with an injection volume of $10 \mu \mathrm{L}$ in split-injection mode. Gradient elution with a constant flow-rate of $1 \mathrm{~mL} / \mathrm{min}$ was carried out with the mobile phase program outlined in Additional file 1. Ion source settings and potentials are shown in Supplementary Information. The instrument was operated with Analyst Software ( $v$ 1.3.1). FT-ICR MS analysis was performed using direct infusion into an FT-ICR MS (ThermoFisher) equipped with nano-ESI ion source, and spectra were acquired and processed with MassWorks software. Elemental composition of peaks was processed with Molecular Weight Calculator for Windows 9x/NT/ 2000/ME/XP (@Matthew Monroe). Emodin standard $(10 \mu \mathrm{g} / \mathrm{mL})$ was used as an external standard for calibrating mass accuracy of peaks in samples. NMR spectra were recorded on Bruker $600 \mathrm{MHz}$ and 800 $\mathrm{MHz}$ Avance III spectrometers equipped with $5 \mathrm{~mm}$ CPTXI cryogenic probes operating at 297 K. Sample volume in deuterated DMSO was $550 \mu \mathrm{L}$. The chemical shift (d) values are given in ppm and coupling constants (J) in Hz. Further NMR parameters are in Additional file 1. ECD spectrum was collected in $\mathrm{MeOH}$ using an Olis DSM 20 CD spectrophotometer and optical rotations were obtained on a Rudolph AUTOPOL IV polarimeter at wavelengths of $365,405,436,546,589$, and $633 \mathrm{~nm}$ using a $1.0 \mathrm{dm}$ cell. Specific rotations are reported in degrees per decimeter at $23^{\circ} \mathrm{C}$ and the concentrations are given in grams per $100 \mathrm{~mL}$ of solvent. Solvent used for optical rotations was $\mathrm{MeOH}$ (100\%).

\section{Construction and validation of ER plasmids}

The human ER $\beta$ expression plasmid (ER $\beta / p c D N A 3)$ was constructed by PCR amplification of the human ER $\beta$ segment (530 aa, GenBank: AF051427.1) out of pCMV5 (kindly provided by Dr. John Katzenellenbogen, University of Illinois) and insertion of this fragment at BstEII and AflII restriction sites into the modified pcDNA3 construct, which was previously described [33]. This construct contains a short $5^{\prime}$-untranslated sequence from the $\beta$-globin promoter and a $3{ }^{\prime}$-untranslated region $(\sim 1.2 \mathrm{~kb})$ from the mouse AhR gene that in previous studies significantly increased the in vitro expression of several proteins ([33] and data not shown). The human $E R \alpha$ expression plasmid, pcDNA3.1 $+E R \alpha$, was purchased from Missouri S\&T cDNA Resouce Center and was confirmed by restriction digestion. The human ER $\alpha$ fragment (444 aa, GenBank: AAD52984.1) from this plasmid was PCR-amplified with primers containing $B s t E I I$ and $A f l \mathrm{II}$ sites, and the plasmid ER $\alpha / \mathrm{pcDNA} 3$ was constructed by inserting this BstEII/AflII fragment into the modified pcDNA3 vector. The generated plasmids were verified by DNA sequencing. Plasmids ER $\beta /$ pcDNA3 and ER $\alpha / p c D N A 3$ were used as templates for in vitro expression (Additional file 2); ER $\alpha$ and ER $\beta$ were synthesized in vitro using the TNT Quick coupled transcription/translation rabbit reticulocyte lysate system (Promega). Briefly, ${ }^{35}$ S-Radiolabeled hER $\alpha$ and hER $\beta$ were synthesized in separate reactions in vitro according to manufacturer's protocol, denatured, and subjected to SDS-polyacrylamide gel electrophoresis, and the $\mathrm{kDa}$ of each protein was determined by autoradiography of the dried gel.

\section{Cell culture and transient transfection assays}

The recombinant BG1Luc4E2 cell-line containing a stably transfected estrogen-responsive luciferase reporter gene was grown and prepared for bioassay analysis as previously described [32]. Briefly, cells in $10 \mathrm{~cm}$ plates of approximately $20 \%$ confluence were cultured in phenol- 
red free DMEM supplemented with $10 \%$ charcoalstripped FBS, for six days with daily media replacement. Cells were then plated into white, clear-bottomed 96well tissue culture plates at a density of 750,000 cells $/ \mathrm{mL}$ and allowed to attach for $24 \mathrm{~h}$. Cells were incubated with carrier solvent EtOH (1\% final solvent concentration), the indicated concentration of $\mathrm{E} 2$, or respective chemical or fraction treatment for $24 \mathrm{~h}$ at $37^{\circ} \mathrm{C}$. Method blank treatments were included if applicable. After incubation cells were washed twice with PBS, followed by addition of cell lysis buffer (Promega), the plates shaken for 20 min at room temperature to allow cell lysis, and luciferase activity in each well was measured using an Orion microplate luminometer as previously described [34]. SKBR3 cells were grown and maintained in high-glucose DMEM and $10 \%$ premium FBS. SKBR3 cells were cultured in phenol red-free medium supplemented with 10\% charcoal-stripped FBS for $48 \mathrm{~h}$ before transfection and seeded in 24-well plates at a density of 300,000 cells/mL. $24 \mathrm{~h}$ after plating, cells were transfected for $24 \mathrm{~h}$ using Lipofectamine reagent $(2 \mu \mathrm{L} /$ well $)$ according to the manufacturer's recommendations $(0.2 \mu \mathrm{g}$ of ERresponsive reporter plasmid pGudLuc7ere [32] and 0.05 $\mu \mathrm{g}$ receptor plasmids (ER $\alpha / \mathrm{pcDNA} 3$ or $\mathrm{ER} \beta / \mathrm{pcDNA} 3)$ or empty vector (pcDNA3.1+) per well, normalizing $\mu \mathrm{g}$ DNA/well to $0.8 \mu \mathrm{g}$ /well with empty vector). $24 \mathrm{~h}$ posttransfection, SKBR3 cells were incubated for $24 \mathrm{~h}$ with chemical, the cells harvested, and both protein concentration and luciferase activity determined. Protein concentration was determined using the Bradford assay [35]. Briefly, $5 \mu \mathrm{L} /$ well SKBR3 lysate was incubated for $5 \mathrm{~min}$ at room temperature with $1 \mathrm{X}$ Bradford Reagent $(200 \mu \mathrm{L})$. Protein concentration was calibrated against a standard curve of bovine serum albumin $(0.05-0.5 \mathrm{mg} / \mathrm{mL})$ on the same plate and was measured as $\mathrm{mg}$ protein $/ \mathrm{mL}$ using a PhosphorImager (Molecular Dynamics).

\section{Statistical analysis}

Luciferase activity was expressed as relative light units (RLU) for assays using BG1Luc4E2 cells or as a ratio of luciferase RLU/mg protein for assays using SKBR3 cells. Protein amount (mg) was calculated from concentrations obtained in Bradford assay and the respective luciferase RLU was divided by $\mathrm{mg}$ protein to obtain luciferase RLU/mg protein. Average luciferase RLU (or luciferase RLU/mg protein) values were calculated from triplicate wells. Solvent luciferase RLU (or luciferase RLU/mg) was subtracted from luciferase RLU induced by chemical. In the case of extract and fractions, luciferase RLU induced by method blank was subtracted from luciferase RLU induced by extract or fraction. Negative values were reported as 0 . Luciferase RLU and luciferase $\mathrm{RLU} / \mathrm{mg}$ protein from rhodoeosein, emodin, and genistein, extracts, and fractions were calculated as a percent of maximum E2 activity (achieved with $1 \mathrm{nM}$ E2 and 10 nM E2 in BG1Luc4E2 cells and SKBR3 cells, respectively, and set as 100\%) as previously described [36]. The Student's $t$-test (2-tailed, paired) was used to establish significant difference of chemical/fraction/extract activity from that of solvent or method blank $(\mathrm{p} \leq 0.05)$, and dose-response curves were fitted using a sigmoidal Hill's 4-parameter algorithm (SigmaPlot v.9.0, Systat, San Jose, CA), as described previously $[37,38]$. Half-maximal inductions of each treatment $\left(\mathrm{EC}_{50}\right)$ were determined as described in [34].

\section{Sample extraction and isolation of (-)-epiafzelechin-3-O- p-coumarate}

Extraction and isolation to determine the estrogenic compounds in F. convolvulus is described in Additional file 1. Seed was extracted using the following optimized protocol. Triple aliquots of ground F. convolvulus seed (25 g) were prepared. A method blank was included. Samples were sonicated in EtOAc $(25 \mathrm{~mL})$ for $7 \mathrm{~min}$ and liquid portions were collected. This process was repeated three times with an additional final solvent rinse of the samples. Liquid portions for each sample were centrifuged and re-centrifuged (550 g force) for $10 \mathrm{~min}$ per centrifugation. Supernatants were collected and the solvent evaporated from each sample at room temperature using nitrogen evaporation. Residues were re-suspended in $\mathrm{EtOH}$ and vacuum filtered using $0.2 \mu \mathrm{m}$ Millipore filters. Solvent was evaporated and residues were resuspended in $\mathrm{H}_{2} \mathrm{O} / \mathrm{ACN}$ (1:1) 0.1\% HOAc for preparative HPLC (Program 2). An isocratic program was carried out with $\mathrm{A}$, water with $0.1 \% \mathrm{HOAc}$, and $\mathrm{B}$, acetonitrile with $0.1 \%$ HOAc. The elution program was as follows: $20-30 \%$ $\mathrm{B}$ in $2 \mathrm{~min}$ ( $1 \mathrm{~mL} / \mathrm{min}), 30 \% \mathrm{~B}$ for $13 \mathrm{~min}$ ( $1 \mathrm{~mL} / \mathrm{min}), 30$ $100 \% \mathrm{~B}$ in $5 \mathrm{~min}(1 \mathrm{~mL} / \mathrm{min})$, with a flush of $100 \% \mathrm{~B}$ for $2 \mathrm{~min}(2 \mathrm{~mL} / \mathrm{min}), 100-20 \% \mathrm{~B}$ in $2 \mathrm{~min}(1 \mathrm{~mL} / \mathrm{min})$, and $20 \% \mathrm{~B}$ for $1 \mathrm{~min}(1 \mathrm{~mL} / \mathrm{min}$ (run-time $23 \mathrm{~min}$ ). Valve (direct to waste) timing was 1.8 min onwards. Fractions were collected in 0.25 min intervals and evaluated for activity in BG1Luc4E2 cells, and fractions 12-14 (containing compound 5) were combined and fractionated resulting in fractions $12-13.5$ that were combined and refractionated to yield pure compound 5 (20.9 mg). Compound 5 ((-)-epiafzelechin-3-O-p-coumarate) was then evaluated for activity at different concentrations in BG1Luc4E2 cells and maximal ER $\alpha$ and ER $\beta$ activity in SKBR3 cells.

\section{Results}

Estrogenic activity of seed extracts and crude fractions

$F$. convolvulus and F. dumetorum seeds were extracted and analyzed for estrogenic activity in human ovarian carcinoma BG1Luc4E2 cells (Figure 1A). The seed extracts of $F$. convolvulus and $F$. dumetorum superinduced 


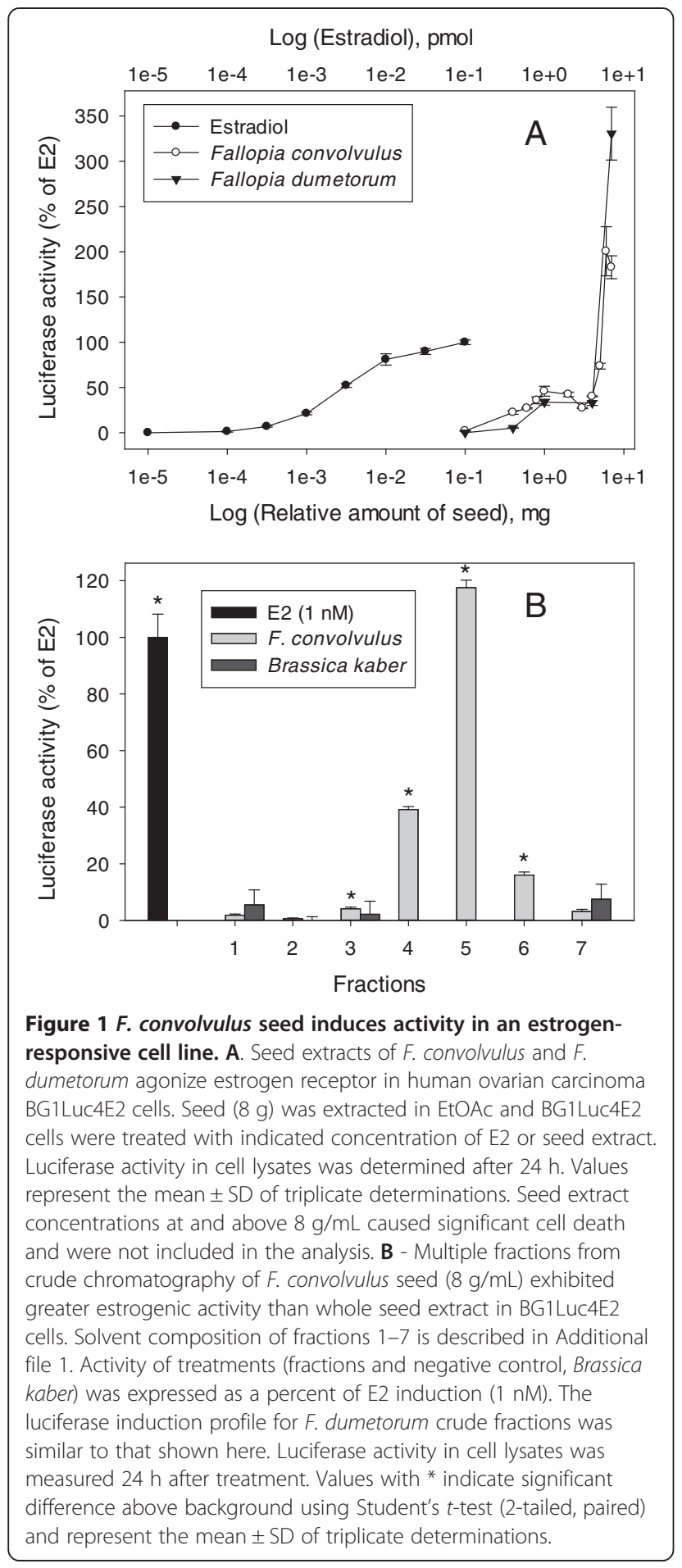

ER-dependent luciferase expression at 200\% and 330\%, respectively, of maximal luciferase levels caused by $17 \beta$ - estradiol (E2). At seed amounts equal to and greater than $8 \mathrm{mg}$ on the bioassay, significant cell death was noted which suggested presence of toxins in the seed extracts (therefore values greater than $7 \mathrm{mg}$ seed are not included in the analysis). The similarity in the luciferase induction pattern between $F$. convolvulus and $F$. dumetorum suggests the seeds of both species may contain very similar estrogenic/antiestrogenic components. The estrogenic properties of seeds from a Fallopia species have not been examined, so comparison to seeds of other Fallopia species is not possible. However, whole root extracts of a related species, $F$. multiflorum, were capable of inducing ER-dependent gene expression to $\sim 75 \%$ of maximal E2 activity (from $0.1 \mathrm{mg}$ root) in a yeast-based estrogen receptor assay [39] and contains an estimated $0.4 \mathrm{mM}$ E2 EQ/g herb in the same receptor assay in a separate study [40]. After initial analysis on BG1Luc4E2 cells, F. convolvulus seed extract was then crudely fractionated using normal phase chromatography, and fractions (8 $\mathrm{mg}$ seed equivalents $/ \mathrm{mL}$ ) were evaluated for estrogenic activity in the BG1Luc4E2 cell line (Figure 1B). Significant luciferase induction was observed in multiple fractions, which suggested that more than one estrogenic agent may be present in the seed extract. Luciferase activity of fraction 5 alone was superinduced to $118 \pm 3 \%$ seed equivalent compared to a toxic response for whole seed extract at the same concentration (Figure 1B) suggesting the fractionation removed some toxins from the whole seed extract during the crude separation. The seed estrogen(s) was/ were suspected to contain both polar and nonpolar characteristics as the eluting solvent of active fractions ranged from $20 \%$ EtOAc in $n$-hex to $5 \% \mathrm{EtOH}$ in EtOAC. Estrogenic potency values of crude fractions were calculated against an E2-dependent luciferase induction standard curve (data not shown) using the methods of Natarajan et al. [37]. Crude fractions 3, 4, and 6 of $F$. convolvulus had respective estrogenic potency values of $0.21,2.4$, and $0.76 \mathrm{nM}$ E2 equivalence (eq) per g seed with $4 \pm 0.6 \%$, $39 \pm 1 \%$, and $16 \pm 1 \%$, respectively of maximal E2 activity. Brassica kaber seed was used as a negative control in the crude fractionation as the seed does not contain phytoestrogens.

\section{Isolation and identification of estrogens from $F$. convolvulus seed}

HPLC-DAD analysis of $F$. convolvulus seed extract showed a minimum of nine phenolic compounds (Additional files 3 and 4). The retention time and UV spectrum of the nine compounds were confirmed in $F$. dumetorum seed extract (Additional file 3). The estrogenic activity of crude fraction 3 from $F$. convolvulus seed extract was attributed to compound 1. For isolation of the remaining estrogenic component(s), active crude fractions 4-6 of F. convolvulus seed were combined and subjected to HPLC fractionation (Figure 2). Using Program $1\left(\mathrm{H}_{2} \mathrm{O} / \mathrm{ACN}\right.$ gradient $), 44$ fractions were collected in $30 \mathrm{~s}$ intervals, fractions were evaporated under a stream of nitrogen, and resuspended in 


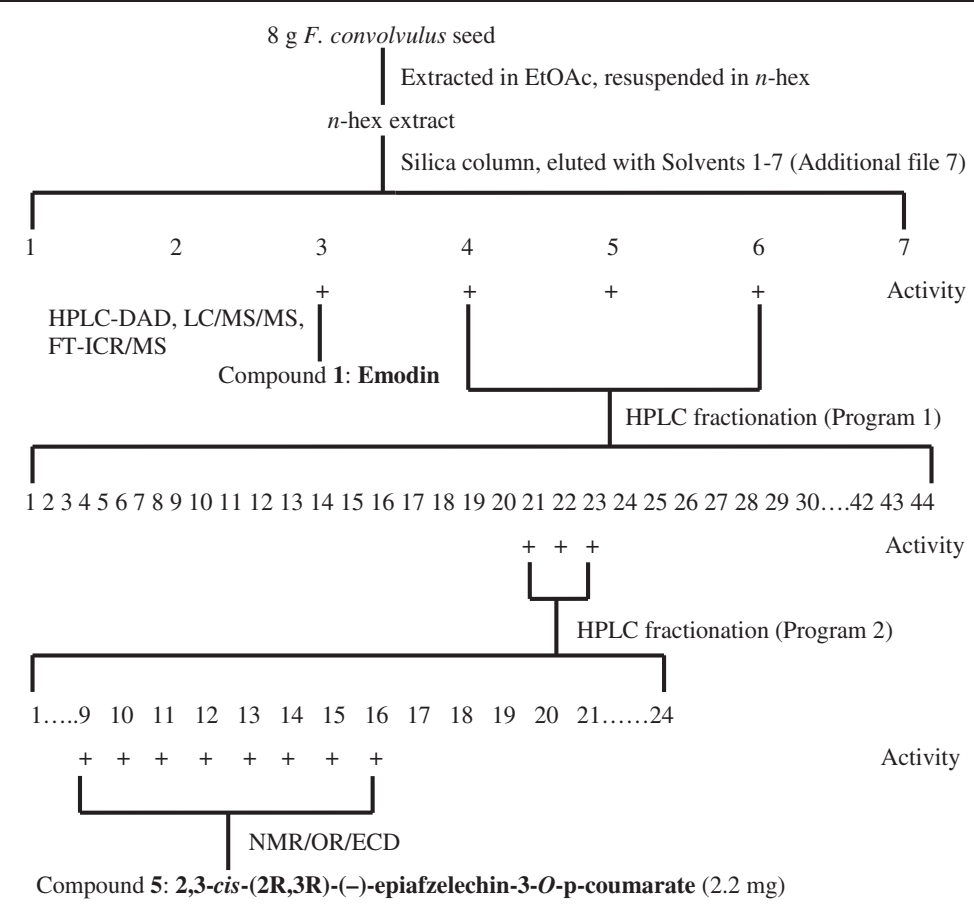

Figure 2 Isolation strategy of estrogenic components from F. convolvulus seed. (+) indicates activity in BG1Luc4E2 cell line. Crude chromatography is described in Additional file 1. HPLC programs 1 and 2 are described in Additional file 1 and Methods, respectively.

$\mathrm{MeOH}$ at a concentration of $8 \mathrm{~g}$ seed equivalents/mL. Fractions were screened for activity using BG1Luc4E2 cells, and active fractions (21-23) were subsequently combined and refractionated using HPLC Program 2. These second-round fractions were screened for activity, and active fractions (9-16) were verified for purity using Program 1 and combined. Compound 5, the purified peak from these fractions, was then identified as described below. While there was an insufficient amount of compound $\mathbf{1}$ for NMR, it was identified as emodin, an anthraquinone derivative, based on retention time, UV-spectrum, mass spectrum (including MRM), and accurate mass (Additional files 1, 3, 4 and 5). In addition to the fractionation scheme showed in Figure 2, we developed an optimized isolation scheme for compound 5 (Additional file 6) in which we were able to isolate $20.9 \mathrm{mg}$ compound $\mathbf{5}$ from $75 \mathrm{~g}$ F. convolvulus seed for subsequent functional analysis.

\section{Chemical characterization of compound 5}

The purified active (estrogenic) sample, compound $\mathbf{5}$ $(2.2 \mathrm{mg})$, was identified by NMR, optical rotation, and circular dichroism as 2,3-cis-(2R,3R)-(-)-epiafzelechin-3$O$-p-coumarate (rhodoeosein, [Figure 3]). Table 1 shows the ${ }^{1} \mathrm{H}$ and ${ }^{13} \mathrm{C}$ shifts of rhodoeosein. Proton and carbon spectra and COSY, NOESY, HMBC and HSQC correlations were obtained to construct rhodoeosein in relative stereochemistry (Additional file 7). COSY correlations from NMR analysis were employed to identify vicinal relationships among the aromatic protons in each parasubstituted phenolic ring. Coupling between $\mathrm{H} 6$ and $\mathrm{H} 8$ was also established. The trans $\mathrm{H} \alpha$ to $\mathrm{H} \beta$ relationship was based upon the magnitude of the vicinal coupling constant $(15.8 \mathrm{~Hz})$ which was obvious in the COSY spectrum. $\mathrm{H} 3$ demonstrated vicinal cross peaks to $\mathrm{H} 4 \alpha$ and $\mathrm{H} 4 \beta$. The trans relationship from $\mathrm{H} 3$ to $\mathrm{H} 4 \beta$ was based upon the larger vicinal coupling constant $(4.9 \mathrm{~Hz})$ as compared to $\mathrm{H} 3$ to $\mathrm{H} 4 \alpha(2.4 \mathrm{~Hz})$. Cross peaks in NOESY from $\mathrm{H} 3$ to $\mathrm{H} \alpha$ and $\mathrm{H} \beta$ suggest a trans

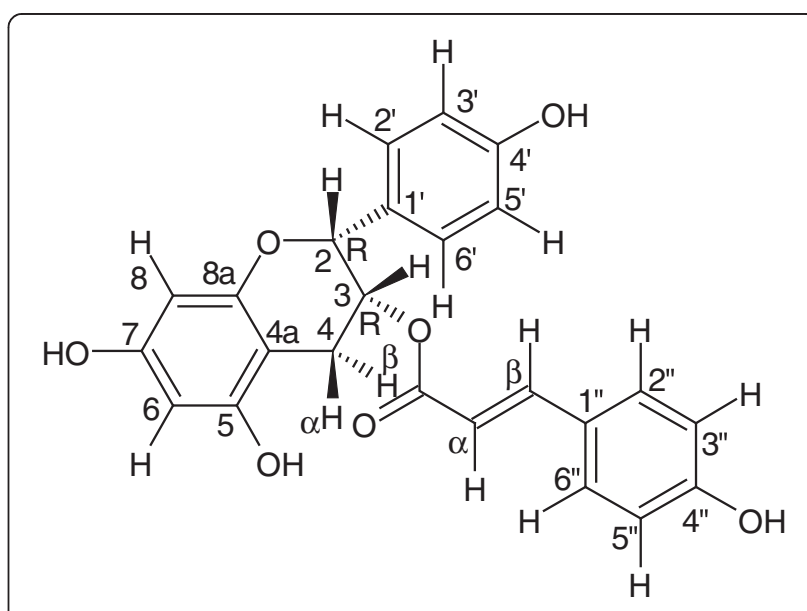

Figure 3 Structure of 2,3-cis-(2R,3R)-(-)-epiafzelechin-3-O-pcoumarate (rhodoeosein), depicted in absolute stereochemistry. 


\begin{tabular}{|c|c|c|c|}
\hline Atom \# & ${ }^{1} \mathrm{H}$ & & ${ }^{13} \mathrm{C}$ \\
\hline 2 & 5.07 & (s) & 76.3 \\
\hline 3 & 5.34 & $(\mathrm{~m})$ & 67.8 \\
\hline $4 a$ & 2.65 & $(\mathrm{dd}, J=17.6,2.4 \mathrm{~Hz})$ & 25.6 \\
\hline $4 \beta$ & 2.92 & $(\mathrm{dd}, J=17.6,4.9 \mathrm{~Hz})$ & 25.6 \\
\hline $4 a$ & & & 97.2 \\
\hline 5 & & & $156.6^{*}$ \\
\hline 6 & 5.94 & $(\mathrm{~d}, J=2.4 \mathrm{~Hz})$ & 95.6 \\
\hline 7 & & & $156.5^{*}$ \\
\hline 8 & 5.79 & $(\mathrm{~d}, J=2.4 \mathrm{~Hz})$ & 94.3 \\
\hline $8 a$ & & & 155.5 \\
\hline $1^{\prime}$ & & & 128.6 \\
\hline $2^{\prime}, 6^{\prime}$ & 7.25 & $(\mathrm{~d}, J=8.6 \mathrm{~Hz})$ & 127.8 \\
\hline $3^{\prime}, 5^{\prime}$ & 6.7 & $(\mathrm{~d}, \mathrm{~J}=8.6 \mathrm{~Hz})$ & 114.8 \\
\hline $4^{\prime}$ & & & 156.9 \\
\hline$C=O$ & & & 166.1 \\
\hline$a$ & 6.25 & $(\mathrm{~d}, \mathrm{~J}=15.8 \mathrm{~Hz})$ & 113.6 \\
\hline$\beta$ & 7.38 & $(\mathrm{~d}, \mathrm{~J}=15.8 \mathrm{~Hz})$ & 145.3 \\
\hline 1" & & & 124.6 \\
\hline 2",6" & 7.5 & $(\mathrm{~d}, \mathrm{~J}=8.6 \mathrm{~Hz})$ & 130.5 \\
\hline 3",5" & 6.72 & $(\mathrm{~d}, \mathrm{~J}=8.6 \mathrm{~Hz})$ & 115.8 \\
\hline $4^{\prime \prime}$ & & & 160.3 \\
\hline
\end{tabular}

Compound was measured in DMSO. Chemical shifts are reported relative to TMS (residual dimethylsulphoxide-D6 $=2.50$ ppm for ${ }^{1} \mathrm{H}$ and $39.51 \mathrm{ppm}$ for ${ }^{13} \mathrm{C}$ ). ${ }^{*}$ Chemical shift assignment for $\mathrm{C} 5$ and $\mathrm{C} 7$ may be reversed. HMBC data did not permit resolution sufficient to unambiguously assign the two resonances. This finding has no impact on the proposed structure. A single broad $-\mathrm{OH}$ resonance was observed at $9.9 \mathrm{ppm}$.

relationship between the carbonyl and the double bond containing $\mathrm{H} \alpha$ and $\mathrm{H} \beta$. A small cross peak was observed between $\mathrm{H} 2$ and $\mathrm{H}_{2}{ }^{\prime} 6$ ' thus supporting the point of attachment of one para-substituted phenolic ring. From the NOESY, H3 showed cross peaks to $\mathrm{H} \alpha$ and $\mathrm{H} \beta$ as well as H2'6'. This supported the connectivity of C3-O-C $=\mathrm{O}-\alpha-\beta . \mathrm{H} \beta$ revealed cross peaks to $\mathrm{H} 6{ }^{\prime \prime}{ }^{\prime \prime}$. This supported the connectivity of $\mathrm{C} \beta$ to $\mathrm{C} 1$ ". $\mathrm{H} 8$ was differentiated from $\mathrm{H} 6$ by cross peaks to $\mathrm{H} 2{ }^{\prime}$ and $\mathrm{H} 2$. Thus $\mathrm{H} 6$ was more distant from either phenolic ring. A weak cross peak from $\mathrm{H} 4 \alpha$ was observed to $\mathrm{H} \beta$ and $\mathrm{H} \alpha$ (not shown). From $\mathrm{HMBC}, \mathrm{H} 3$ showed a fundamental correlation to $\mathrm{C}=\mathrm{O}$ further supporting the connectivity of $\mathrm{C} 3-\mathrm{O}-\mathrm{C}=\mathrm{O} . \mathrm{H} \beta$ yielded cross peaks to $\mathrm{C} 2$ " 6 " indicating the attachment of $\mathrm{C} \beta$ to $\mathrm{C} 1$ ". Cross peaks from $\mathrm{H} 2$ to $\mathrm{C} 2{ }^{\prime} 6^{\prime}$ indicated the connectivity of $\mathrm{C} 2$ to $\mathrm{C} 1$ '. Other important correlations were revealed with cross peaks from $\mathrm{H} 4 \alpha$ and $\mathrm{H} 4 \mathrm{\beta}$ to $\mathrm{C} 4 \mathrm{a}$ and C8a. $\mathrm{H} 8$ showed correlations to $\mathrm{C} 7$ and C8a. Also, H6 exhibited correlation to $\mathrm{C} 4 \mathrm{a}, \mathrm{C} 7$ and $\mathrm{C} 5$. The combination of this information led to the unique assignments of carbons in the bicyclic ring $(\mathrm{C} 2-\mathrm{C} 8 \mathrm{a})$ and also supported the connectivity of the remaining moieties. Resolution of the $\mathrm{HMBC}$ experiment did not permit differentiation between C5 and C7. The resonances were separated by only 0.1 ppm. The assignments of these two resonances could be reversed without impacting any other assignments or the proposed structure. Regarding the absolute stereochemistry, rhodoeosein contains two stereogenic centers (C2, C3, Figure 3). As the majority of cis flavan-3-ols from natural sources exist in the $2 \mathrm{R}, 3 \mathrm{R}$ conformation [41,42], it was not surprising that optical rotation combined with electronic circular dichroism (ECD) indicated the absolute stereochemistry of rhodoeosein as 2R,3R (Figure 4). Optical rotation values were negative at all tested wavelengths at two different concentrations of rhodoeosein in $\mathrm{MeOH}$ (Additional file 7) which is in agreement with the parent compound, (2R,3R)-(-)-epiafzelechin [43]. ECD spectra were calculated for the $2 \mathrm{R}, 3 \mathrm{R}$ conformation of rhodoeosein using B3LYP and CAM-B3LYP predictions and compared to the experimental spectrum (Figure 4). The overlay of experimental ECD spectrum on predicted spectra indicated good agreement for a $2 \mathrm{R}, 3 \mathrm{R}$ confirmation of rhodoeosein. The predicted ECD calculations (the CAM-B3LYP prediction was adjusted $+20 \mathrm{~nm}$ ) for the $2 \mathrm{R}, 3 \mathrm{R}$ confirmation of rhodoeosein showed a positive $\mathrm{L}_{\mathrm{a}}$ transition at ca.230 nm (corresponding to 3R), matching that of the experimental ECD (Figure 4) and of the Boltzmann-weighted parent compound [43-45]. The $\mathrm{L}_{\mathrm{b}}$ transition for the experimental spectrum of rhodoeosein occurred at ca.300-310 $\mathrm{nm}$ whereas the $\mathrm{L}_{\mathrm{b}}$ transition for the predicted ECD spectra of the 2R,3R confirmation of rhodoeosein occurred at ca.290 nm; however both predicted and experimental spectra showed a negative $\mathrm{L}_{b}$ transition which corresponds to an $\mathrm{R}$ conformation at $\mathrm{C} 2$ [41] (it should be noted that both the experimental and calculated $\mathrm{L}_{\mathrm{b}}$ transitions for rhodoeosein were outside the

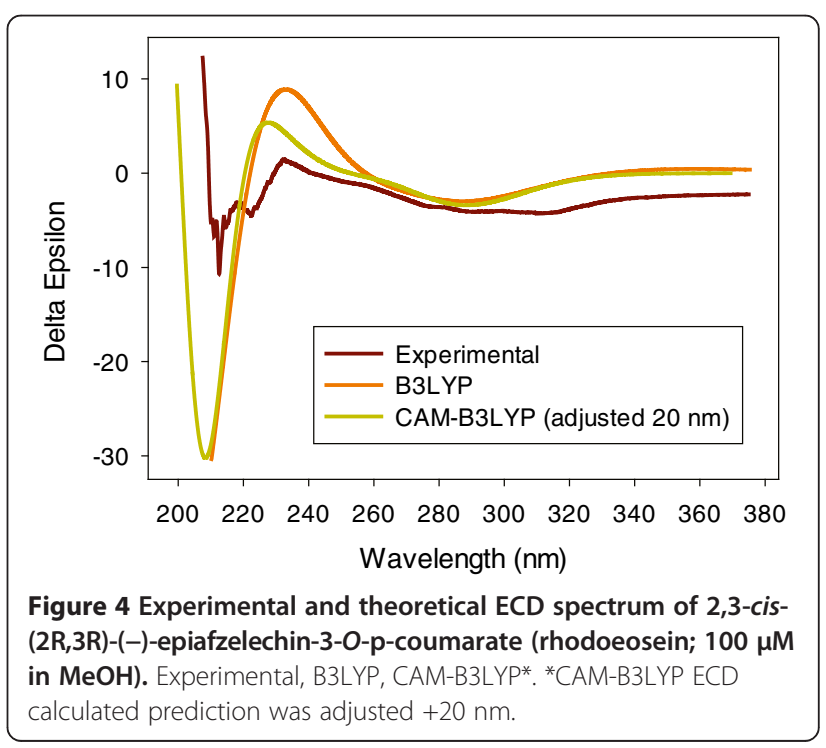


traditional range of the $\mathrm{L}_{\mathrm{b}}$ transition for flavan-3-ols which is 260-280 $\mathrm{nm}$ [46]). The parent compound, (2R,3R)(-)-epiafzelechin, also displays a negative $\mathrm{L}_{\mathrm{b}}$ transition [43-45]. From the mass spectrum of rhodoeosein, a parent peak and a dimer of the parent peak were noted at $419 \mathrm{~m} / \mathrm{z}$ ([M-1]) and $839 \mathrm{~m} / \mathrm{z}$ ([2M-1]), respectively (Additional file 7). Fragment peak $145 \mathrm{~m} / \mathrm{z}$ was interpreted as the 3-O-p-coumarate portion of rhodoeosein (with the remainder of the molecule as fragment $273 \mathrm{~m} / \mathrm{z}$ ).

\section{2,3-cis-(2R,3R)-(-)-epiafzelechin-3-O-p-coumarate (rhodoeosein)}

Translucent pink oily film from 70/30 $\mathrm{H}_{2} \mathrm{O} / \mathrm{ACN}$; pink in $\mathrm{MeOH}$ and $\mathrm{EtOH} ; \alpha]_{23} \mathrm{D}-151$ (c 0.22, MeOH); For ${ }^{1} \mathrm{H}$ and ${ }^{13} \mathrm{C}$ NMR spectroscopic data, see Table 1 ; for CD data $(\mathrm{MeOH})$, see Figure 4; ESIMS m/z: 840.5 [2M], 419.4 $[\mathrm{M}-1], 273,254.9,229.1,164.9,145: 419.11360[\mathrm{M}-\mathrm{H}]^{-}$ $\left(\mathrm{C}_{24} \mathrm{H}_{19} \mathrm{O}_{7}\right.$, experimental 419.11322, calc 419.11307). For peak abundances, UV spectrum, HMBC, HSQC, NOESY, and COSY spectra, see Additional file 4: Table S1 and Additional file 7 .

\section{Biological characterization of rhodoeosein and emodin}

To characterize the estrogen activity of the novel phytoestrogen, rhodoeosein, we analyzed its activity over a range of concentrations in two human cell lines: a recombinant human ovarian carcinoma (BG1Luc4E2) cell line [32] and a human breast carcinoma (SKBR3) cell line. In addition to E2, we also compared the activity of rhodoeosein with that of emodin and of a well-known phytoestrogen control, genistein. Both rhodoeosein and emodin induced luciferase induction in the stablytransfected BG1Luc4E2 cells. Rhodoeosein had a narrow range of luciferase-inducing concentrations in BG1Luc4E2 cells (Figure 5); incubation with rhodoeosein below 31.6 $\mu \mathrm{M}$ resulted in no luciferase induction whereas incubation with $119 \mu \mathrm{M}$ and $158 \mu \mathrm{M}$ rhodoeosein resulted in superinduction of ER-dependent luciferase in BG1Luc4E2 cells ( $>400 \%$ of maximum E2 activity). Incubation with rhodoeosein at concentrations at or above $250 \mu \mathrm{M}$ killed BG1Luc4E2 cells (no toxicity was observed at $197 \mu \mathrm{M}$ rhodoeosein). Based on maximum luciferase induction at $158 \mu \mathrm{M}$ rhodoeosein, $\mathrm{EC}_{50}$ of rhodoeosein was $120 \mu \mathrm{M} \pm 0.360 \mu \mathrm{M}$ rhodoeosein, approximately 7 orders of magnitude weaker in potency than the E2 standard (Figure 5, Table 2). As a comparison, emodin displayed half-maximal activity in BG1Luc4E2 cells at $1.3 \mu \mathrm{M}$ emodin, approximately 5 orders of magnitude weaker in potency than the E2 standard $\left(\mathrm{EC}_{50} 18 \mathrm{pM} \pm\right.$ $9.4 \mathrm{nM}$ ) and was able to induce luciferase to $104 \pm 3 \%$ of maximum E2 activity (Figure 5, Table 2). Emodin's estrogenic properties have been previously demonstrated in a recombinant yeast screening assay (YES) containing ER $\alpha$; emodin was only two orders of

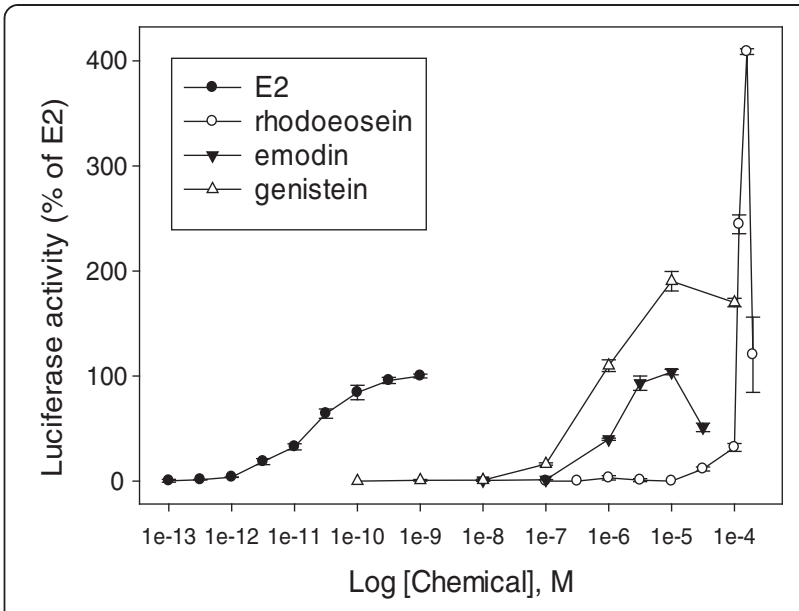

Figure 5 Potency curves of phytoestrogens rhodoeosein and emodin in human ovarian carcinoma BG1Luc4E2 cells. $\bullet=E 2$; $\mathrm{O}=$ rhodoeosein; $\boldsymbol{\nabla}=$ emodin; $\Delta$ = genistein. Rhodoeosein was able to superinduce luciferase activity in BG1Luc4E2 cells. Luciferase activity was expressed as a percent of the maximum induction by E2 (1 nM) and was determined in cell lysates $24 \mathrm{~h}$ after treatment. Incubation of cells with $0.25,0.316$, and $1 \mathrm{mM}$ rhodoeosein caused cell death and these values were not included in above analysis. Values represent the mean \pm SD of triplicate determinations.

magnitude weaker in estrogen response than the E2 standard [12]. When assessing genistein's activity in BG1Luc4E2 cells, we found genistein was able to superinduce luciferase $(190 \pm 9 \%$ of maximum E2 activity) and was, not surprisingly, more potent than either rhodoeosein or emodin with half-maximal induction at $0.73 \mu \mathrm{M} \pm 0.15 \mu \mathrm{M}$ (approximately 4 orders of magnitude weaker than the E2 standard).

Although the BG1Luc4E2 cell line endogenously expresses $E R \alpha$, it does not appear to express ER $\beta$ protein [32]. Given the critical role that ER $\beta$ plays in normal physiological/endocrinological processes and tissue health and in modulating the functional activity and levels of ER $\alpha$ [47-50], interest in ligands that selectively interact with ER $\beta$ has grown. To evaluate activity of rhodoeosein and emodin on both ER subtypes, rhodoeosin was incubated with SKBR3 cells transiently co-transfected with an estrogen-response firefly luciferase reporter plasmid [32] and either an ER $\beta$ (ER $\beta$ / pcDNA3) or ER $\alpha(E R \alpha / p c D N A 3)$ expression plasmid. Firefly luciferase activity in each well was normalized to protein amount and the resulting ratio expressed as a percent of maximum induction by E2 (10 nM). In contrast to the results BG1Luc4E2 cells, rhodoeosein did not superinduce ER-dependent gene expression in SKBR3 cells transfected with either ER subtype; maximum luciferase induction by rhodoeosein was $78 \pm 8 \%$ and $80 \pm 10 \%$ of E2 activity in SKBR3 cells transfected with either ER $\alpha$ or ER $\beta$, respectively (Figure 6). Concentrations of rhodoeosein greater than $100 \mu \mathrm{M}$ rhodoeosein 
Table 2 Potency comparisons of phytoestrogens

\begin{tabular}{lllll}
\hline & \multicolumn{2}{l}{ EC 5 (M), REP } & & \\
\cline { 2 - 5 } Cell-line & E2 & Rhodoeosein & Emodin & Genistein \\
\hline BG1LuC4E2 & $1.8 \times 10^{-11}, 1$ & $1.2 \times 10^{-4}, 3.5 \times 10^{-7}$ & $1.3 \times 10^{-6}, 1.5 \times 10^{-5}$ & $7.3 \times 10^{-7}, 2.5 \times 10^{-5}$ \\
SKBR3 (ERa) & $2.0 \times 10^{-11}, 1$ & $5.8 \times 10^{-6}, 4.0 \times 10^{-6}$ & $1.3 \times 10^{-6}, 1.5 \times 10^{-5}$ & $9.0 \times 10^{-7}, 2.2 \times 10^{-5}$ \\
SKBR3 (ER3) & $2.7 \times 10^{-10}, 1$ & $1.8 \times 10^{-5}, 1.8 \times 10^{-5}$ & $3.0 \times 10^{-6}, 8.9 \times 10^{-5}$ & $8.3 \times 10^{-8}, 3.3 \times 10^{-3}$ \\
\hline
\end{tabular}

Comparison of concentration for half-maximal induction $\left(E_{50}\right)$ and relative estrogenic potency (REP) for E2, rhodoeosein, and emodin in human carcinoma celllines BG1Luc4E2 (ovarian) and SKBR3 (breast) transfected with either ERa or ER 3 . Data for genistein is included for comparative purposes. $\mathrm{REP}=\mathrm{EC} \mathrm{F}_{50}$ $\mathrm{E} 2 / \mathrm{EC}_{50}$ chemical.

resulted in significantly decreased protein concentration in SKBR3 cells and are not included in the analysis. Halfmaximal induction $\left(\mathrm{EC}_{50}\right)$ by rhodoeosein in $\mathrm{ER} \alpha$ - and ER $\beta$-transfected SKBR3 cells was $5.8 \mu \mathrm{M} \pm 1.5 \mu \mathrm{M}$ and $18 \mu \mathrm{M} \pm 0.4 \mu \mathrm{M}$, respectively (significantly less potent than E2 which had $\mathrm{EC}_{50}$ values of $20 \mathrm{pM} \pm 1.5 \mathrm{nM}$ and $270 \mathrm{pM} \pm 4.0 \mathrm{nM}$ in ER $\alpha$ - and ER $\beta$-transfected SKBR3 cells, respectively). The phytoestrogen control, genistein, superinduced at $10 \mu \mathrm{M}$ genistein in ER $\alpha$-transfected cells, but did not significantly superinduce in ER $\beta$-transfected cells. Genistein was the only phytoestrogen in this study to exhibit a lower $\mathrm{EC}_{50}$ value in ER $\beta$-transfected SKBR3 cells than in $E R \alpha$-transfected SKBR3 cells $\left(E_{50}\right.$ values $83 \pm 120 \mathrm{nM}$ and $0.90 \pm 0.88 \mu \mathrm{M}$, respectively). Concentrations of genstein greater than $10 \mu \mathrm{M}$ resulted in significantly decreased RLU in SKBR3 cells and are not included in the analysis. Emodin was also evaluated in ER-transfected SKBR3 cells; maximum induction by emodin was significantly greater than that of E2 in ER $\alpha$-transfected but not ER $\beta$-transfected SKBR3 cells

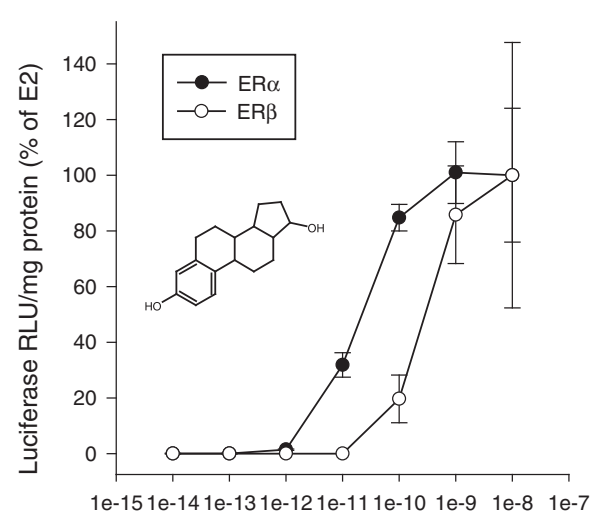

Log [E2], M

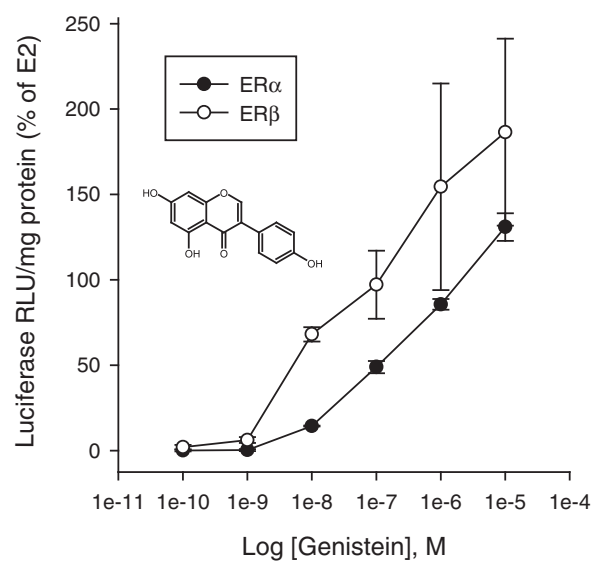

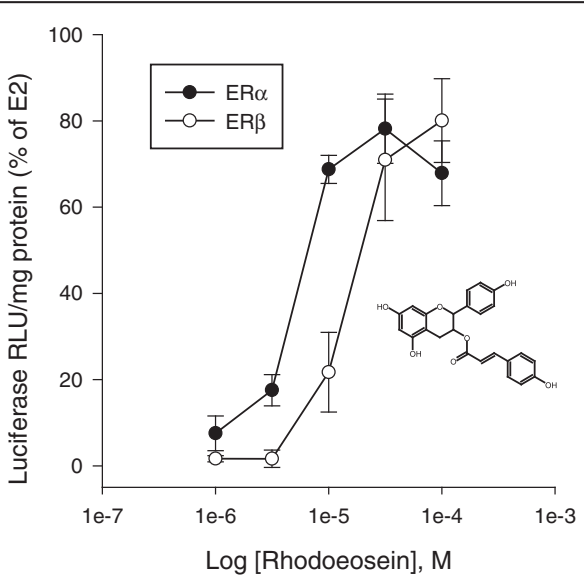

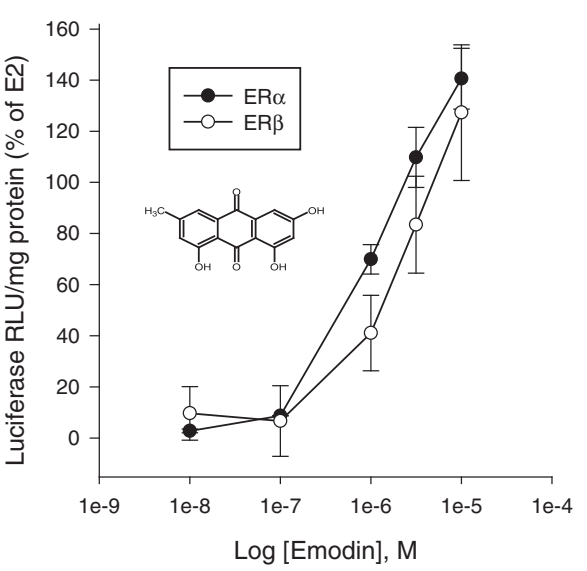

Figure 6 Phytoestrogens rhodoeosein and emodin isolated from $F$. convolvulus seed induce luciferase expression in human breast carcinoma SKBR3 cells transiently transfected with ERa or ER $\beta$. • = ERa-transfected SBKR3 cells; O = ERß-transfected SKBR3 cells. Luciferase activity was normalized with protein concentration, was expressed as a percent of the maximum induction by E2 (10 nM), and was determined in cell lysates $24 \mathrm{~h}$ after treatment. Values represent the mean \pm SD of triplicate determinations. Incubation of SKBR3 cells with $0.316 \mathrm{mM}$ rhodoeosein caused cell death and was not included in the above analysis. 
with $141 \pm 12 \%$ and $127 \pm 26 \%$ of maximum E2 activity, respectively (Figure 6). Concentrations of emodin greater than $10 \mu \mathrm{M}$ were toxic to SKBR3 cells and therefore are not included in the analysis. $\mathrm{EC}_{50}$ values for emodin in ER $\alpha$-transfected and ER $\beta$-transfected SKBR3 cells were $1.3 \mu \mathrm{M} \pm 0.24 \mu \mathrm{M}$ and $3.0 \mu \mathrm{M} \pm 1.0 \mu \mathrm{M}$, respectively, (as compared to emodin's $E_{50}$ value of 1.3 $\mu \mathrm{M}$ in BG1Luc4E2 cells). While emodin was a more potent phytoestrogen than rhodoeosein for both ER $\alpha$ and $\operatorname{ER} \beta$, it is present at much lower concentrations in the seed (Additional file 4), and as such, rhodoeosein likely is responsible for a greater amount of the estrogenic activity of whole seed.

\section{Discussion}

Consumption of a diet rich in phytoestrogens has been strongly correlated with beneficial effects on human health [51,52]. Flavan-3-ols (the subclass of compounds containing rhodoeosein) have been reported to have a wide array of positive health effects such as antioxidant, anti-viral, anticarcinogenic, antimicrobial, and cardiopreventation (reviewed in [53]). Aside from the current study, there is no report of phytoestrogenic activity associated with flavan-3-ols. However, flavonoids, the broad class of plant compounds under which flavan-3-ol is found, contains many phytoestrogens (genistein, biochanin A, daidzein). Thorough structure-function analyses of various flavonoids on estrogen-responsive cell lines have correlated hydroxyls at the 7 and 4 ' positions in flavonoids to those at the 17 and 3 positions in E2 and concluded that the flavonoid hydroxyls are essential for estrogenic activity $[54,55]$. The estrogenic flavonoids in these two studies contained between 2 to 4 hydroxyl substituents. Accordingly, it is not surprising that rhodoeosein is estrogenic since it contains hydroxyls at the 7 and 4' positions (Figure 3) and displays the classic A-ring structure which is shared by all known estrogenic compounds [56]. A further phenomenon that may allow for the estrogenic activity of rhodoeosein is increased acidity of a hydroxyl through in-plane hydrogen bonding as suggested for other compounds by Fang et al. [56]. Rhodoeosein possesses a benzylic hydrogen, $\mathrm{H}_{\beta}$, that is in close proximity to an ester on $\mathrm{C}=\mathrm{O}$ (in conjugation with a hydroxyl in the 4 " position). This ester may be able to form an intramolecular $\mathrm{H}$-bond with the in-plane $\mathrm{C} 4 \mathrm{H}_{\beta}$ (Figure 3); the increased electron-withdrawing capability of the $\mathrm{C}=\mathrm{O}$ carbonyl from an $\mathrm{H}$-bond interaction with the $\mathrm{C} 4 \mathrm{H}_{\beta}$ would increase the acidity of the 4" hydroxyl (favorable for ER activity). In Zand et al. [55], a double bond between carbons 2 and 3 was important for estrogenic activity of a flavonoid as the double bond at this position increased rigidity of the molecule and, therefore, ERaffinity [56]; interestingly, rhodoeosein lacks a double bond at this position in the molecule but contains, in addition to the A- and B-rings, a large conjugated system exhibiting rigidity (-O-p-coumarate) which may lend favorable ER-binding attributes to the molecule. It may be that the structurally-favorable aspects of rhodoeosein (hydroxyls at the 7 and 4' positions, having 4 hydroxyl substituents, rigidity) outweigh the absence of a double bond between C2 and C3. Additionally, molecules exhibiting a certain measure of hydrophobicity (where the molecule is hydrophobic while containing a polar group on each end) bind to ER with greater affinity [56]. Rhodoeosein contains not just one set of opposing polar groups but two $(7-\mathrm{OH}$ and $4^{\prime}-\mathrm{OH}, 7-\mathrm{OH}$ and $4{ }^{\prime \prime}-\mathrm{OH}$ ) which sandwich large hydrophobic regions (Figure 3).

Plants have a complex pathway for flavan-3-ol formation. Flavan-3-ols can be found in the seeds and fruits but not leaves of certain plants, and a pathway for flavonoid conversion in the plant from flavanone to flavan3-ol has been proposed [45]. The gene responsible for the formation of flavan-3-ol through this cascade is highly expressed in the seeds but not in the flowers or leaf tissues [45]. Recently, F. convolvulus roots were examined for polyphenolic content [19]. Except for emodin, none of the 20 polyphenolic compounds (3 new, 17 known) found in the roots seem to exist in the seeds of F. convolvulus (based on mass spectrometry supplementary data). This curious phenomenon of the polyphenolic content of the seeds being unrepresentative of the content in the roots (aside from emodin) may be explained through the multi-step flavonoid pathway illustrated in Xie et al. [45]. It is thought that flavan-3-ols (known as tannins in plants) play a mainly defensive role in the plant against herbivorous animals, insects, fungi, and other harmful agents [53]. However, as demonstrated here and in other studies, flavan-3-ols exhibit complex biological properties in human systems.

Although emodin's behavior in ER $\alpha$-transfected SKBR3 cells and BG1Luc4E2 cells was consistent (Table 2), rhodoeosein showed marked cell-specific differences in the potency and magnitude of luciferase induction between BG1Luc4E2 cells and ER $\alpha$-transfected SKBR3 cells (Table 2). Luciferase activity was induced by rhodoeosein in BG1Luc4E2 cells to a level greater than that maximally induced by E2 and this superinduction response suggests that rhodoeosein is also affecting other signaling pathways that impact on ER-dependent activation of luciferase expression from the reporter plasmid. Numerous studies have not only demonstrated that the functional activities of ER and other steroid hormone receptors can be altered by posttranslational modifications (i.e. phosphorylation, acetylation and others), but phosphorylation can also activate the transcriptional activity of these receptors in the absence of ligand 
binding [57-60]. Binding of ligand to a cytosol-membrane ERs or to GPR30 (a G-coupled protein receptor) can activate protein-kinase cascades which phosphorylate and activate nuclear ERs as well as other signaling pathways and transcription factors [57]. For example, tectoridin, a flavonoid phytoestrogen, was found to exert its estrogenic effects not through the ER but through an extracellular signal-regulated kinase pathway [61]. Additionally, direct or indirect stimulation of growth factor receptors can lead to activation of protein-kinase cascades and hormone receptor-dependent and independent gene expression responses. The enhancement of reporter gene expression observed with rhodoeosein treatment in BG1Luc4E2 cells but not SKBR3 cells could result from a rhodoeoseindependent stimulation of an additional signaling pathway (s) that enhances the transcription of the luciferase reporter gene promoter. This pathway(s) may not present or affected in the SKBR3 cells. Although superinduction has been previously observed in the BG1Luc4E2 cell line [38], the molecular mechanism responsible for superinduction of ER-dependent gene expression in BG1Luc4E2 cells remains to be elucidated.

Regarding half-maximal concentration differences between the two ER subtypes, we did not find that rhodoeosein or emodin had lower $\mathrm{EC}_{50}$ values in $\mathrm{ER} \beta$ transfected SKBR3 cells than in ER $\alpha$-transfected SKBR3 cells which does not agree with previous literature on phytoestrogens $[13,62]$. However, the ER $\beta$-transfected SKBR3 cells appear to be an order of magnitude less responsive to ER-ligands than the ER $\alpha$-transfected SKBR3 cells as shown by the $\mathrm{EC}_{50}$ values of $\mathrm{E} 2$, rhodoeosein, and emodin in both transfections (Table 2). Therefore, we choose to assess potency by comparing the $\mathrm{EC}_{50}$ values of emodin and rhodoeosein directly to those of the E2 standards in the ER $\alpha$-transfected cells and the ER $\beta$-transfected cells (Table 2). This method of using relative estrogenic potency (REP) has been previously established in [63] where REP was defined as the ratio between $\mathrm{E} 2 \mathrm{EC}_{50}$ and $\mathrm{EC}_{50}$ of the chemical. We have also defined $\mathrm{REP}=\mathrm{EC}_{50}$ of $\mathrm{E} 2 / \mathrm{EC}_{50}$ of phytoestrogen, and when compared to the half-maximal concentration of the E2 standard, both emodin and rhodoeosein were more potent in ER $\beta$-transfected SKBR3 cells than in ER $\alpha$-transfected SKBR3 cells (Table 2). REP of rhodoeosein in ER $\alpha$-transfected SKBR3 cells was $3.4 \times$ $10^{-6}$ but in ER $\beta$-transfected SKBR3 cells was $1.5 \times 10^{-5}$, a 4-fold increase in REP. The difference between emodin's REP values in ER $\alpha$-transfected SKBR3 cells and ER $\beta$-transfected SKBR3 cells was similar to that of rhodoeosein; REP of emodin in ER $\beta$-transfected SKBR3 cells was $8.9 \times 10^{-5}$ whereas in ER $\alpha$-transfected SKBR3 cells, the REP was $1.5 \times 10^{-5}$, a 6 -fold decrease. This is in agreement with [62] where A YES assay transfected separately with ER $\alpha$ or ER $\beta$ was used to examine emodin's estrogenic activity; emodin had greater REP in $E R \beta$-transfected yeast cells than in ER $\alpha$-transfected yeast cells by approximately one order of magnitude. Our findings are also in agreement with a study examining binding affinity of several phytoestrogens to either ER $\alpha$ or ER $\beta$; compared to the E2 standard (set as 100\%), relative binding affinity of genistein, biochanin A, coumestrol, and diadzein were greater to ER $\beta$ than to ER $\alpha$ [64]. In our assay, the control phytoestrogen genistein showed a 146fold increase in REP for ER $\beta$ compared to ER $\alpha$ (REP values $3.3 \times 10^{-2}$ and $2.2 \times 10^{-5}$, respectively), in agreement with [63]. ER $\alpha$ and ER $\beta$ have unique and overlapping tissue distribution in the human body, and the roles of the ER subtypes in the human body are now becoming more clear (reviewed in [65] and [52]). Although ER $\beta$ activation may be associated with certain deleterious effects (i.e. potential involvement in metabolic disorders leading to diabetes [65]), beneficial roles of ER $\beta$ in the human body include development and maintenance of the brain, ovulation, prostate health, and anti-proliferative roles in certain breast cancers. The effectiveness of phytoestrogens, which exist in nature not as single compounds but as complex mixtures in food matrices, as therapeutic agents for existing diseases is still unclear, but epidemiological studies indicate diets containing a significant amount of phytoestrogens seem to correlate with ER $\beta$-mediated benefits (such as decreased incidence of breast and prostate cancers). The higher REP values displayed by rhodoeosein and emodin in ER $\beta$-transfected cells may indicate use of foods containing these compounds as part of a comprehensive plan for maintaining tissue health through ER $\beta$ mediated activity.

\section{Conclusion}

Seeds of F. convolvulus were identified as a novel source of phytoestrogens from which we have isolated and chemically characterized a novel phytoestrogen rhodoeosein. Estrogenic activity of rhodoeosein was evaluated in two human cell-lines in which we were able to demonstrate cell-type specific effects of rhodoeosein. To our knowledge, rhodoeosein is the first published flavan-3-ol to demonstrate estrogenic properties in vitro. In addition to rhodoeosein, we also found that $F$. convolvulus seed contains emodin (a known and potent estrogen), and these compounds were also identified in the closely-related species $F$. dumetorum. By comparing relative estrogenic potencies (REP) of emodin and rhodoeosein in SKBR3 cells transfected with either ER $\alpha$ or ER $\beta$ we found that both phytoestrogens are more potent in ER $\beta$-transfected cells than in ER $\alpha$-transfected cells and that emodin is more potent than rhodoeosein on both ER subtypes. Similar differences in potency were observed in the BG1Luc4E2 cell line. The estrogenic compounds in this study may regulate 
reproduction to some degree in wildlife consuming these seeds [38]. Effects in vivo have not yet been assessed, but the complex polyphenolic content of $F$. convolvulus seed may indicate therapeutic potential.

\section{Additional files}

Additional file 1: Supplemental text. Further details of the isolation

Additional file 2: Validation of ER plasmids and the SKBR3 cell line. In vitro expression of the ER/pcDNA3 plasmids and a control transfection experiment using SKBR3 cells.

Additional file 3: HPLC chromatograms of $F$. convolvulus seed and crude fractions. HPLC chromatograms of active (estrogenic) crude fractions and whole seed extracts.

Additional file 4: Table S1. Retention times, relative abundance, and elemental composition of pure standards and polyphenolic compounds of interest from F. convolvulus seed (shown as chomatographic peaks 1-9 which correspond to compounds 1-9). Table S2. Validation of HPLC-DAD method. Table S3. Declustering potential (DP), Ionization potential (FP), Entrance potential (EP), Collision Energy (CE), Collision cell entrance potential (CEP), Collision cell exit potential (CXP) and dwell time of selected transitions for the emodin standard.

Additional file 5: Comparison of compound 1 (in F. convolvulus seed) to emodin standard. UV spectrum, mass spectrum, and MRM transitions of compound1 (emodin).

Additional file 6: Optimized fractionation scheme for isolation of 2,3-cis-(2R,3R)-(-)-epiafzelechin-3-O-p-coumarate from $F$. convolvulus seed.

Additional file 7: Chemical characterization data for compound 5 (2,3-cis-(2R,3R)-(-)-epiafzelechin-3-O-p-coumarate [rhodoeosein]). UV-spectrum, mass spectra, optical rotation, and NMR spectra and correlations of rhodoeosein (isolated from F. convolvulus seed).

\section{Abbreviations}

ER: Estrogen receptor; MS: Mass spectrometry; DAD: Diode array detection; UV: Ultra-violet; ESI: Electrospray ionization; FTICR: Fourier transform ion cyclotron resonance; NMR: Nuclear magnetic resonance; CD: Circular dichroism; ECD: Electronic circular dichroism; TIE: Toxicant identification evaluation; $\mathrm{EC}_{50}$ : Effective concentration 50; MRM: Multiple reaction monitoring; eq: Equivalence; HMBC: Heteronuclear Multiple Bond Correlation; COSY: Correlation spectroscopy; NOESY: Nuclear Overhauser effect spectroscopy; HSQC: Heteronuclear Single Quantum Coherence; REP: Relative estrogenic potency.

\section{Competing interests}

The authors declare that they have no competing interests.

\section{Authors' contributions}

$\mathrm{JM}$ and $\mathrm{JB}$ designed the experiment with significant input from $\mathrm{MD}$ and $\mathrm{DH}$. JB did fractionation (isolation), HPLC-DAD analyses, bioassay analyses, and drafted the paper. MD, DH, and PM provided valuable expertise and advice on different steps of the project. DH did HPLC/MS/MS analyses and advised on FT-ICR/MS analyses. JD ran NMR analysis of rhodoeosein. PM elucidated rhodoeosein's structure and relative stereochemistry. JD confirmed rhodoeosein's structure elucidation, constructed Table 1, Figure 3, and all supplemental NMR figures regarding rhodoeosein. EG did ECD analysis for rhodoeosein. AS designed ER/pCDNA vectors and did in vitro expression. All authors provided feedback to JB during the drafting process. All authors read and approved the final manuscript.

\section{Acknowledgements}

We thank Dr. John Katzenellenbogen for the pCMV5-ERß construct. We also thank Charles Grove for optical rotation data collection, Dr. Annaliese Franz for advice and expertise on circular dichroism, and Dr. Dean Tantillo for expertise and advice on intramolecular forces. We thank the National Science
Foundation (grant \#0314510 to JM.), the National Institute of Environmental Health Sciences (grant ESO04699 to MD and the T32 training grant T32 ES007058-33 to JB), and the University of California, Davis (Jastro-Shields to JB) for funding. We wish to acknowledge equipment grants NIH RR11973 for the $600 \mathrm{MHz}$ NMR and NSF DBIO 727538 for the $800 \mathrm{MHz}$ NMR.

\section{Author details}

${ }^{1}$ Department of Environmental Toxicology, University of California, One Shields Avenue, Davis, CA 95616, USA. ${ }^{2}$ Agricultural and Natural Resources Analytical Laboratory, University of California, One Shields Avenue, Davis, CA 95616, USA. ${ }^{3}$ Department of Pharmacognosy and Natural Products Chemistry, Faculty of Pharmacy, University of Athens, Panepistimioupolis Zografou 15 771, Athens, Greece. ${ }^{4}$ Nuclear Magnetic Resonance (NMR) Facility Office, University of California, One Shields Avenue, Davis, CA 95616, USA. ${ }^{5}$ Department of Chemistry, One Shields Avenue, Davis, CA 95616, USA. ${ }^{6}$ Department of Animal Science, University of California, One Shields Avenue, Davis, CA 95616, USA.

Received: 5 July 2012 Accepted: 22 May 2013

Published: 14 June 2013

\section{References}

1. Chen HS, Liu Y, Lin LQ, Zhao JL, Zhang CP, Jin JC, Wang L, Bai MH, Wang YC, Liu M, et al: Anti-proliferative effect of an extract of the root of Polygonum multiflorum Thunb. on MCF-7 human breast cancer cells and the possible mechanisms. Molecular Medicine Reports 2011, 4(6):1313-1319.

2. Zhang $\mathrm{QH}$, Yang JY, Wang DF, Wu CF: Genotoxic studies on Panax Ginseng, Polygonum multiflorum and their compatibility in mouse peripheral lymphocyte cells. Acta Pharmacol Sin 2006, 27:288.

3. Zhang $Y Z$, Shen JF, Xu JY, Xiao JH, Wang $J$ : Inhibitory effects of $2,3,5,4$ '-tetrahydroxystilbene-2-O-beta-D-glucosid on experimental inflammation and cyclooxygenase 2 activity. J Asian Nat Prod Res 2007 9(4):355-363.

4. Liao SG, Zhang LJ, Sun F, Zhang JJ, Chen AY, Lan YY, Li YJ, Wang AM, He X, Xiong $Y$, et al: Antibacterial and anti-inflammatory effects of extracts and fractions from Polygonum capitatum. J Ethnopharmacol 2011, 134(3): 1006-1009.

5. Fremont L: Minireview - Biological effects of resveratrol. Life Sci 2000, 66(8):663-673.

6. Li-Shuang LV, Gu XH, Ho CT, Tang J: Stilbene glycosides from the roots of Polygonum multiflorum Thunb and their in vitro antioxidant activities. Journal of Food Lipids 2006, 13(2):131-144.

7. Noda T, Yamada T, Ohkubo T, Omura T, Ono T, Adachi T, Awaya T, Tasaki Y, Shimizu K, Matsubara K: Hot-water-extracts of Polygonum Multiflorum Do Not Induce Any Toxicity but Elicit Limited Beneficial Effects on the Liver in Mice. Journal of Health Science 2009, 55(5):720-725.

8. Matsuda H, Shimoda H, Morikawa T, Yoshikawa M: Phytoestrogens from the roots of Polygonum cuspidatum (Polygonaceae): structurerequirement of hydroxyanthraquinones for estrogenic activity. Bioorg Med Chem Lett 2001, 11(14):1839-1842.

9. Avula B, Josfh VC, Wang YH, Khan KA: Simultaneous identification and quantification of anthraquinones, polydatin, and resveratrol in Polygonum mutiflorum, various Polygonum species, and dietary supplements by liquid chromatography and microscopic study of Polygonum species. J AOAC Int 2007, 90(6):1532-1538.

10. Shen MY, Liu YJ, Don MJ, Liu HY, Chen ZW, Mettling C, Corbeau P, Chiang CK, Jang YS, Li TH, et al: Combined Phytochemistry and Chemotaxis Assays for Identification and Mechanistic Analysis of Anti-Inflammatory Phytochemicals in Fallopia japonica. PLoS One 2011, 6:11.

11. Zhang CZ, Wang SX, Zhang Y, Chen JP, Liang XM: In vitro estrogenic activities of Chinese medicinal plants traditionally used for the management of menopausal symptoms. J Ethnopharmacol 2005, 98(3):295-300

12. Zhang CN, Zhang XZ, Zhang $Y, X u$ Q, Xiao HB, Liang XM: Analysis of estrogenic compounds in Polygonum cuspidatum by bioassay and high performance liquid chromatography. J Ethnopharmacol 2006, 105(1-2):223-228.

13. Harris DM, Besselink E, Henning SM, Go VLW, Heber D: Phytoestrogens induce differential estrogen receptor alpha- or beta-mediated responses in transfected breast cancer cells. Exp Biol Med 2005, 230(8):558-568. 
14. Adlercreutz H: Phyto-oestrogens and cancer. Lancet Oncol 2002, 3(6):364-373.

15. Covaleda AMS, Van den Berg H, Vervoort J, Van der Saag P, Strom A Gustafsson JA, Rietjens I, Murk AJ: Influence of cellular ER alpha/ER beta ratio on the ER alpha-agonist induced proliferation of human T47D breast cancer cells. Toxicol Sci 2008, 105(2):303-311.

16. Sotoca AM, Ratman D, van der Saag P, Strom A, Gustafsson JA, Vervoort J, Rietjens I, Murk AJ: Phytoestrogen-mediated inhibition of proliferation of the human T47D breast cancer cells depends on the ER alpha/ER beta ratio. J Steroid Biochem Mol Biol 2008, 112(4-5):171-178.

17. Williams C, Edvardsson K, Lewandowski SA, Strom A, Gustafsson JA: A genome-wide study of the repressive effects of estrogen receptor beta on estrogen receptor alpha signaling in breast cancer cells. Oncogene 2008, 27(7):1019-1032.

18. Klein $\mathrm{H}$ : black bindweed Fallopia convolvulus (Linnaeus) A. Love or Polygonum convolvulus. Alaska, USA: University of Alaska, Anchorage; 2011:1-3.

19. Zhang CF, Chen J, Zhao LQ, Zhang D, Zhang MA, Wang ZT: Three new flavonoids from the active extract of Fallopia convolvulus. J Asian Nat Prod Res 2011, 13(2):136-142.

20. USDA, ARS, National Genetic Resources Program: Fallopia convolvulus (L.). Germplasm Resources Information Network (GRIN). Beltsville, Maryland: National Germplasm Resources Laboratory; 2011. http://www.ars-grin.gov/ cgi-bin/npgs/html/taxon.pl?40459. Web. 622013.

21. Helbaek H: Prehistoric food plants and weeds in Denmark. A survey of archaeobotanical research 1923-1954. Danmarks Geol Undersogelse 2 Raekke 1954, 80:250-261

22. Behre KE: Collected seeds and fruits from herbs as prehistoric food. Vegetation History and Archaeobotany 2008, 17(1):65-73.

23. Arroo RRJ, Androutsopoulos V, Beresford K, Ruparelia K, Surichan S, Wilsher $\mathrm{N}$, Potter GA: Phytoestrogens as natural prodrugs in cancer prevention: dietary flavonoids. Phytochemistry Reviews 2009, 8(2):375-386.

24. Fan PH, Marston A, Hay AE, Hostettmann K: Rapid separation of three glucosylated resveratrol analogues from the invasive plant Polygonum cuspidatum by high-speed countercurrent chromatography. J Sep Sci 2009, 32(17):2979-2984.

25. Pickford R, Miguens-Rodriguez M, Afzaal S, Speir P, Pergantis SA, Thomas Oates JE: Application of the high mass accuracy capabilities of FT-ICR-MS and Q-ToF-MS to the characterisation of arsenic compounds in complex biological matrices. Journal of Analytical Atomic Spectrometry 2002, 17(3): 173-176.

26. Yao S, Li Y, Kong LY: Preparative isolation and purification of chemical constituents from the root of Polygonum multiflorum by high-speed counter-current chromatography. J Chromatogr A 2006, 1115(1-2):64-71.

27. Xu ML, Zheng MS, Lee YK, Moon DC, Lee CS, Woo MH, Jeong BS, Lee ES, Jahng Y, Chang HW, et al: A new stilbene glucoside from the roots of Polygonum multiflorum Thunb. Arch Pharm Res 2006, 29(11):946-951.

28. Kwit M, Rozwadowska MD, Gawronski J, Grajewska A: Density Functional Theory Calculations of the Optical Rotation and Electronic Circular Dichroism: The Absolute Configuration of the Highly Flexible transIsocytoxazone Revised. J Org Chem 2009, 74(21):8051-8063.

29. Zhang CN, Wang XM, Zhang XZ, Zhang Y, Xiao HB, Liang XM: Bioassayguided Separation of Citreorosein and Other Oestrogenic Compounds From Polygonum cuspidatum. Phytother Res 2009, 23(5):740-741.

30. Shan B, Cai YZ, Brooks JD, Corke H: Antibacterial properties of Polygonum cuspidatum roots and their major bioactive constituents. Food Chem 2008, 109(3):530-537.

31. Lin HW, Sun MX, Wang YH, Yang LM, Yang YR, Huang N, Xuan LJ, Xu YM, Bai DL, Zheng YT, et al: Anti-HIV Activities of the Compounds Isolated from Polygonum cuspidatum and Polygonum multiflorum. Planta Med 2010, 76(9):889-892.

32. Rogers JM, Denison MS: Recombinant cell bioassays for endocrine disruptors: Development of a stably transfected human ovarian cell line for the detection of estrogenic and anti-estrogenic chemicals. In Vitro \& Molecular Toxicology-a Journal of Basic and Applied Research 2000, 13(1):67-82

33. Soshilov A, Denison MS: Role of the Per/Arnt/Sim Domains in Liganddependent Transformation of the Aryl Hydrocarbon Receptor. J Biol Chem 2008, 283(47):32995-33005.

34. Baston DS, Denison MS: Considerations for potency equivalent calculations in the Ah receptor-based CALUX bioassay: Normalization of superinduction results for improved sample potency estimation. Talanta 2011, 83(5):1415-1421.
35. Bradford MM: Rapid and sensitive method for quantitation of microgram quantities of protein utilizing principle of protein-dye binding. Anal Biochem 1976, 72(1-2):248-254.

36. Seidel SD, Li V, Winter GM, Rogers WJ, Martinez El, Denison MS: Ah receptor-based chemical screening bioassays: Application and limitations for the detection of Ah receptor agonists. Toxicol Sci 2000, 55(1):107-115

37. Natarajan K, Overstreet JW, Rogers JM, Denison MJ, Chen JG, Lohstroh PN, McConnell DS, Lasley BL: Detection of xenoestrogens in serum after immunoprecipitation of endogenous steroidal estrogens. Environ Health Perspect 2002, 110(8):791-795.

38. Rochester JR, Klasing KC, Stevenson L, Denison MS, Berry W, Millam JR: Dietary red clover (Trifolium pratense) induces oviduct growth and decreases ovary and testes growth in Japanese quail chicks. Reprod Toxicol 2009, 27(1):63-71.

39. Kang SC, Lee CM, Choi H, Lee JH, Oh JS, Kwak JH, Zee OP: Evaluation of oriental medicinal herbs for estrogenic and antiproliferative activities. Phytother Res 2006, 20(11):1017-1019.

40. Klein KO, Janfaza M, Wong JA, Chang RJ: Estrogen bioactivity in fo-ti and other herbs used for their estrogen-like effects as determined by a recombinant cell bioassay. J Clin Endocrinol Metab 2003, 88(9):4077-4079.

41. Slade D, Ferreira D, Marais JPJ: Circular dichroism, a powerful tool for the assessment of absolute configuration of flavonoids. Phytochemistry 2005 66(18):2177-2215.

42. Kofink M, Papagiannopoulos M, Galensa R: Enantioseparation of catechin and epicatechin in plant food by chiral capillary electrophoresis. European Food Research and Technology 2007, 225(3-4):569-577.

43. Kpegba K, Agbonon A, Petrovic AG, Amouzou E, Gbeassor M, Proni G, Nesnas N: Epiafzelechin from the Root Bark of Cassia sieberiana: Detection by DART Mass Spectrometry, Spectroscopic Characterization, and Antioxidant Properties. J Nat Prod 2011, 74(3):455-459.

44. Korver O, Wilkins CK: Circular dichroism spectra of flavanols. Tetrahedron 1971, 27(22):5459.

45. Xie DY, Sharma SB, Paiva NL, Ferreira D, Dixon RA: Role of anthocyanidin reductase, encoded by BANYULS in plant flavonoid biosynthesis. Science 2003, 299(5605):396-399.

46. van Rensburg H, Steynberg PJ, Burger JFW, van Heerden PS, Ferreira D: Circular dichroic properties of flavan-3-ols. Journal of Chemical Research-S 1999, 7:450-451

47. Couse JF, Korach KS: Estrogen receptor null mice: What have we learned and where will they lead us? Endocr Rev 1999, 20(3):358-417.

48. Strom A, Hartman J, Foster JS, Kietz S, Wimalasena J, Gustafsson JA: Estrogen receptor beta inhibits 17 beta-estradiol-stimulated proliferation of the breast cancer cell line T47D. Proc Natl Acad Sci U S A 2004, 101(6): 1566-1571.

49. Helguero LA, Faulds MH, Gustafsson JA, Haldosen LA: Estrogen receptors alfa (ER alpha) and beta (ER beta) differentially regulate proliferation and apoptosis of the normal murine mammary epithelial cell line HC11. Oncogene 2005, 24(44):6605-6616.

50. Harris HA: Estrogen receptor-beta: Recent lessons from in vivo studies. Mol Endocrinol 2007, 21(1):1-13.

51. Adlercreutz H: Lignans and human health. Crit Rev Clin Lab Sci 2007, 44(5-6):483-525.

52. Hartman J, Strom A, Gustafsson JA: Estrogen receptor beta in breast cancer-Diagnostic and therapeutic implications. Steroids 2009, 74(8):635-641.

53. Aron PM, Kennedy JA: Flavan-3-ols: Nature, occurrence and biological activity. Mol Nutr Food Res 2008, 52(1):79-104.

54. Le Bail JC, Varnat F, Nicolas JC, Habrioux G: Estrogenic and antiproliferative activities on MCF-7 human breast cancer cells by flavonoids. Cancer Lett 1998, 130(1-2):209-216.

55. Zand RSR, Jenkins DJA, Diamandis EP: Steroid hormone activity of flavonoids and related compounds. Breast Cancer Res Treat 2000, 62(1):35-49.

56. Fang H, Tong WD, Shi LM, Blair R, Perkins R, Branham W, Hass BS, Xie Q, Dial $\mathrm{SL}$, Moland $\mathrm{CL}$, et al: Structure-activity relationships for a large diverse set of natural, synthetic, and environmental estrogens. Chem Res Toxicol 2001, 14(3):280-294.

57. Gambino YP, Maymo JL, Perez AP, Calvo JC, Sanchez-Margalet V, Varone CL: Elsevier Trophoblast Research Award Lecture: Molecular mechanisms underlying estrogen functions in trophoblastic cells - Focus on leptin expression. Placenta 2012, 33:S63-\$70. 
58. Bjornstrom L, Sjoberg M: Mechanisms of estrogen receptor signaling: Convergence of genomic and nongenomic actions on target genes. Mol Endocrinol 2005, 19(4):833-842.

59. Ward RD, Weigel NL: Steroid receptor phosphorylation: Assigning function to site-specific phosphorylation. Biofactors 2009, 35(6):528-536.

60. Weigel NL, Moore NL: Cyclins, cyclin dependent kinases, and regulation of steroid receptor action. Mol Cell Endocrinol 2007, 265:157-161.

61. Kang K, Lee S, Jung S, Cha K, Park W, Sohn Y, Nho C: Tectoridin, a poor ligand of estrogen receptor alpha, exerts its estrogenic effects via an ERK-dependent pathway. Mol Cells 2009, 27(3):351-357.

62. Chu WL, Shiizaki K, Kawanishi M, Kondo M, Yagi T: Validation of a New Yeast-Based Reporter Assay Consisting of Human Estrogen Receptors alpha/beta and Coactivator SRC-1: Application for Detection of Estrogenic Activity in Environmental Samples. Environ Toxicol 2009, 24(5):513-521.

63. Bovee TFH, Helsdingen RJR, Rietjens I, Keijer J, Hoogenboom R: Rapid yeast estrogen bioassays stably expressing human estrogen receptors alpha and beta, and green fluorescent protein: a comparison of different compounds with both receptor types. J Steroid Biochem Mol Biol 2004, 91(3):99-109.

64. Escande A, Pillon A, Servant N, Cravedi JP, Larrea F, Muhn P, Nicolas JC, Cavailles V, Balaguer P: Evaluation of ligand selectivity using reporter cell lines stably expressing estrogen receptor alpha or beta. Biochem Pharmacol 2006, 71(10):1459-1469.

65. Nilsson S, Koehler KF, Gustafsson J-A: Development of subtype-selective oestrogen receptor-based therapeutics. Nat Rev Drug Discov 2011, 10(10):778-792.

doi:10.1186/1472-6882-13-133

Cite this article as: Brennan et al:: 2,3-cis-2R,3R-(-)-epiafzelechin-3-O-pcoumarate, a novel flavan-3-ol isolated from Fallopia convolvulus seed, is an estrogen receptor agonist in human cell lines. BMC Complementary and Alternative Medicine 2013 13:133.

\section{Submit your next manuscript to BioMed Central and take full advantage of:}

- Convenient online submission

- Thorough peer review

- No space constraints or color figure charges

- Immediate publication on acceptance

- Inclusion in PubMed, CAS, Scopus and Google Scholar

- Research which is freely available for redistribution 